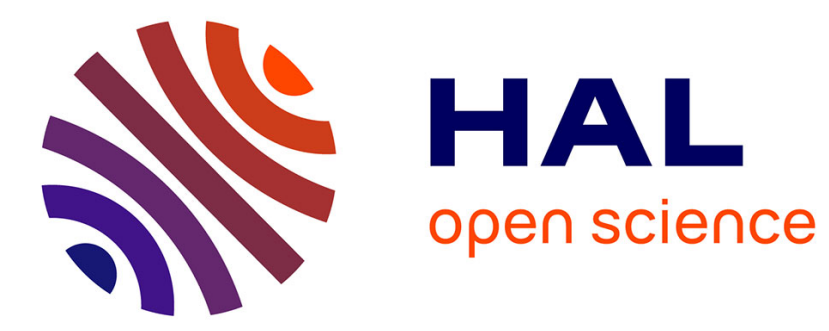

\title{
Late Miocene large mammals from Mahmutgazi, Denizli province, Western Turkey.
}

Denis Geraads

\section{To cite this version:}

Denis Geraads. Late Miocene large mammals from Mahmutgazi, Denizli province, Western Turkey. - Neues Jahrbuch für Geologie und Paläontologie - Abhandlungen, 2017, 284 (3), pp.241-257. 10.1127/njgpa/2017/0661 . halshs-01794188

\section{HAL Id: halshs-01794188 \\ https://shs.hal.science/halshs-01794188}

Submitted on 17 May 2018

HAL is a multi-disciplinary open access archive for the deposit and dissemination of scientific research documents, whether they are published or not. The documents may come from teaching and research institutions in France or abroad, or from public or private research centers.
L'archive ouverte pluridisciplinaire HAL, est destinée au dépôt et à la diffusion de documents scientifiques de niveau recherche, publiés ou non, émanant des établissements d'enseignement et de recherche français ou étrangers, des laboratoires publics ou privés. 
GERAADS, D. 2017. Late Miocene large mammals from Mahmutgazi, Denizli province,

Western Turkey. Neues Jahrbuch für Geologie und Paläontologie, 284(3): 241-257.

Denis GERAADS, CR2P, Sorbonne Universités, MNHN, CNRS, UPMC, CP 38, 8 rue Buffon, 75231 PARIS Cedex 05, France

denis.geraads@mnhn.fr

Abstract: The upper Miocene locality of Mahmutgazi in Western Turkey was excavated in the 70s by a German team, but most of its large mammals had never been studied. The collection housed in the Staatliches Museum für Naturkunde, Karlsruhe, contains, besides previously published groups, large samples of Giraffidae (Samotherium), Rhinocerotidae (including a nice complete skull of Ceratotherium neumayri), and Equidae, as well as some Chalicotheriidae (Ancylotherium) and Bovidae (Boselaphini), which are studied here. Three fossiliferous spots, Ma1, Ma2, and Ma3 have been recognized but I regard the first two, and probably also the third one, as contemporaneous. Although the fossil assemblage certainly does not reflect the full original taxonomic diversity, tentative biochronological conclusions can be proposed: the site is probably older than Şerefköy, Akkaşdağ1, and the 'Dominant Fossil Assemblage' of Samos, but definitely younger than the early part of the Samos sequence.

Key words: Mammalia, Neogene, Turkey, biochronology

\section{Introduction}

The locality of Mahmutgazi in Western Turkey was excavated by SICKENBERG and colleagues in the 70s but, although preliminary results were provided (SICKENBERG et al. 1975), most of the fauna of large mammals remains unpublished. Exceptions are the Carnivora (SCHMIDT-KITTLER 1976), the Proboscidea (GAZIRY 1976), part of the Bovidae (KöHLER 1987), and the Suidae (PICKFORD 2016). During a visit to the Staatliches Museum für Naturkunde in Karlsruhe (SMNK) in December 2016, I studied the whole collection of large ungulates stored there, except the suids. Although it is not a large collection by comparison with several other sites of the Eastern Mediterranean, it is well-preserved and includes some excellent specimens.

The coordinates of the locality Mahmutgazi were provided by PICKFORD (2016) as $38^{\circ} 01^{\prime} 27.0 " \mathrm{~N}, 2^{\circ} 24^{\prime} 34.9^{\prime \prime} \mathrm{E}$. These coordinates correspond well with field notes preserved in the SMNK and can be considered as satisfactory within $\pm 50 \mathrm{~m}$. The locality includes two main 
fossil spots, Ma1 and Ma2, about $50 \mathrm{~m}$ apart in the same stratigraphic layer (W. MunK, pers. comm.); an unpublished photo annotated by H. TOBIEN in the SMNK also shows Ma1, Ma2, and Ma3 at the same level. Indeed, although no data regarding the stratigraphy has been published, Tables 1 to 3 show that there is no consistent difference in size between the Giraffidae from Ma1 and Ma2, confirming that the assemblages from these spots can be regarded as a single fauna. BECKER-PLATEN et al. also regarded Mahmutgazi as a single site, but the example of the nearby site of Kemiklitepe, or of several Greek localities, where geographically very close fossiliferous spots yield distinct faunas, urges caution. Thus, I shall discuss separately the few specimens from Ma3. The collection remains largely un-accessioned, and many specimens are listed below by their locality number and the number of the plaster that contained them (Gips X).

Although no taphonomic analysis has been undertaken, the anatomical composition of the taphocenosis is far from faithfully reflecting that of living animals; this is especially true of the giraffes, whose limb bone collection consists almost entirely of adult or sub-adult specimens, probably from just a few individuals, whereas most of the teeth are deciduous; rhinoceros deciduous teeth are also more common than juvenile limb-bones. An attritional process would have accumulated a greater range of wear stages, with especially more senile individuals, and some sorting must have occurred at Mahmutgazi, either by carnivores or by running water; it may be that the fossil assemblage derives from one or a few catastrophic event(s) that preserved only an incomplete sample of the paleocommunity.

Abbreviations: $\mathrm{APD}=$ anteroposterior diameter $;$ dist. $=$ distal $; \min .=$ minimum $; \max .=$ maximum; prox. $=$ proximal $\mathrm{TD}=$ transverse diameter $\mathrm{H}=$ height $\mathrm{W}=$ width $. \mathrm{EUMI}=$ Aegean University Museum, Izmir; MNHN = Muséum National d'Histoire Naturelle, Paris; NHMA = Natural History Museum, Asenovgrad, Bulgaria; NHMUK = Natural History Museum, London. Measurements are in mm. Upper teeth are in upper case, lower teeth in lower case.

\section{Systematic Palaeontology}

Order Cetartiodactyla Montgelard, CATZEFlis \& DOUZERy, 1997

Family Suidae GRAY, 1821

'Hippopotamodon' erymanthius ROTH \& WAGNER, 1854 
As mentioned above, the suids have recently been revised by PICKFORD (2016) who assigned them to this species, often included in Microstonyx.

\author{
Family Giraffidae GRAY, 1821 \\ Genus Samotherium F. MAJOR, 1888 \\ Samotherium major BOHLIN, 1926
}

Description and comparisons: This taxon is represented by a number of postcranials and several dental remains. The size range of the DP3s is perhaps greater than expected in a single species but all other remains, including the postcranials, are of homogeneous dimensions, and it is more parsimonious to assume that a single species is present.

Ma2-Gips29 (Fig. 1B) is the only adult maxilla. The teeth are imperfectly preserved, but only slightly worn, preserving prominent styles and pillars. The premolars are rather large but P4 remains much narrower than M1; they bear strong spurs in the central valley, as may happen in Samotherium (BoHLIN 1926, pl.5, fig.10).

The best specimen is a partial mandible from Ma3 with the left i2-c and p2-m3; unfortunately part of the diastema is missing, so that its length is unknown (Fig. 1A). As in other Samotherium, the two lobes of the canine are much less clearly distinct than in Giraffa, and this tooth is not much larger than the incisors. The front teeth show no evidence of the interstitial wear that is observed in some other late Miocene large giraffids of the Aegean region, such as Helladotherium from Hadjidimovo, Bulgaria (GERAADS et al. 2005), Samotherium major from Vathylakkos, Greece (GERAADS 1974; MERCERON et al. in press), or S. neumayri from Maragha, Iran (RODLER \& WeITHOFER 1890, p1.4, figs.2-3). This peculiar wear, which is certainly linked with their use as a comb when browsing, is also variably present in Giraffa camelopardalis. The premolars are strongly molarized: p2 has a long entocristid; p3 is similar to $\mathrm{p} 4$ in having a long metaconid connected to the paraconid, but not to the transverse cristid, and blocking the entrance to the mesosinusid; the ectoflexid of p4 is deep, as in other Giraffidae, but the heavy wear has connected the hypoconid to the rest of the tooth. These premolars are also quite short, with a $\mathrm{Pm} / \mathrm{M}$ index of 58.6 (Table 1). These short, molarized premolars suffice to identify the Mahmutgazi large giraffid as Samotherium. In the large Helladotherium, a genus common in Aegean sites of similar age, the premolars are significantly larger, and p3 always retains a primitive morphology. Most representatives of the species S. boissieri from Samos also retain this primitive morphology (BOHLIN 1926, figs.141-146; Kostopoulos 2009a, Fig. 8), but S. neumayri from Maragha and S. major from Vathylakkos 
and Samos (Bohlin 1926; GerAads 1974; Kostopoulos 2009a) have a fully molarized p3. The shortening of the premolars also fits better S. major $(\mathrm{Pm} / \mathrm{M}$ index $=53.8-66.2$, mean $=$ $59.5, \mathrm{~N}=6)$ than $S$. boissieri $(\mathrm{Pm} / \mathrm{M}$ index $=60.7-65.6$, mean $=63, \mathrm{~N}=5)$ (measurements from GERAADS 1974; Kostopoulos 2009a, tab. 8). However, the absolute size of the teeth (Table 1) is lower than in S. major, and closer to S. boissieri.

Upper DP3s (Fig. 1K) have a relatively short first lobe; lower dp3s (Fig. 1L) also have large metaconids completely closing the mesosinusid, and the first lobe of dp4 is fully formed, with no labial arm; these are all derived features, usually found in Samotherium.

The postcranial sample is large. There are no less than nine distal humeri, five of them from the right side, providing a Minimum Number of Individuals of five for the whole collection. It is likely that all these postcranials are indeed from a limited number of individuals, but they cannot be matched, because a single plaster jacket may have contained bones of more than one individuals (Ma2-Gips20 has two right metacarpals).

The dimensions of the distal humeri (Table 2) are homogeneous, but there is no complete bone (Fig. 1E). The available sample of measurements from nearby sites is small; these humeri are clearly larger than those of $S$. boissieri from Samos (dist.TD = 98-106 according to Kostopoulos [2009a]), but smaller than those of its likely descendant S. major from the same area (dist.TD =132-148). The Mahmutgazi humeri also compare well with the forms from the two levels of Kemiklitepe (KTD, lower, and KTA, upper: GERAADS 1994), and with $S$. neumayri from Maragha.

There are six more or less complete metapodials (Table 3); the measurements of the metacarpals (Fig. 1F-H) clearly plot with S. major (Fig. 2).

There are three tibiae (Fig. 1C-D), whose measurements (Table 4) are clearly more similar to those of S. major than to those of S. boissieri.

There are only four astragali, two of them well preserved (Fig. 1J). One is similar in size to those from KTD, and the other to those from KTA (GERAADS 1994), but they also fit S. neumayri from Maragha (pers. data). It is remarkable that, while the size distinction between the two levels of the nearby site of Kemiklitepe is clear, the size of the Mahmutgazi material overlaps both of them (Fig. 3), but the difference in size between the two well-preserved specimens does not exceed what is found in a single population.

A number of other bones (carpals, tarsals, calcanei, phalanges) obviously belong to the same species; the first phalanges are short and stout, as in Samotherium (GERAADS 1974); the cubo-navicular has no posterior articular facet for the metatarsal (Fig. 1I), as in other 
Samotherium, but in contrast to Helladotherium, in which it is present (GERAADS 1974; KostopoulOS 2009a).

Discussion: All postcranials can easily be assigned to Samotherium major, and the derived lower premolars fit this identification, but the lower teeth from Ma3 are smaller than in this species. If indeed Ma3 is contemporaneous with Ma1 and Ma2, these teeth may be from a small individual of $S$. major. In terms of biochronology, $S$. major clearly allies Ma1 and Ma2 with the upper part of the Samos sequence (Kostopoulos 2009a, fig.21).

\section{Family Bovidae GRAY, 1821}

The SMNK collection contains only a few tooth rows, but no postcranials or horn cores; this is a very unlikely anatomical composition for a late Miocene Aegean site, and some of them must be stored elsewhere, but I have been unable to locate them. KÖHLER (1987) described some more cranial remains, now stored in the Geozentrum Hannover. I have not seen them, and her identifications were based upon very limited material. She listed:

- Tragoportax gaudryi, based upon a maxilla (M1-M3 = 53.8); its measurements indeed fit what SPASSOV \& GERAADS (2004) called Miotragocerus(Pikermicerus) gaudryi. In addition, a mandible in the SMNK (Fig. 1N) also fits this species in size and very long premolars (p2-p4 = $47.5 ; \mathrm{m} 1-\mathrm{m} 3=62$ ), and this identification can be accepted.

- Tragoportax amalthea, based upon a good sample of tooth rows; the genus identification is also acceptable, according to her fig. 11; a maxilla in the SMNK (Fig. 1M) probably also belongs here.

- Pseudotragus parvidens; the horn-core cross-section (KöHLER 1987, fig. 58) does indeed resemble that of this species, now placed in Sporadotragus (see, e.g., GERAADS et al. 2006a), but the identification remains ambiguous.

- 'Plesiaddax' cf. inundatus, based upon mandibular pieces, including an m3 reaching a length of $40 \mathrm{~mm}$; in the Aegean region, such a large size is reached only by this species, defined at Garkin (ERDBRINK 1978), so that this identification is probably correct.

- Gazella sp., 'Form IVa'; the horn-core cross-section and measurements would fit G. capricornis, and I tentatively assign them to this species.

- Gazella sp., 'Form V'; this species is mostly illustrated by a hornless skull, whose dental dimensions are also very similar to those of G. capricornis, a species whose females are said by Kostopoulos (2009b) to be hornless, and it is more parsimonious to also identify 'Form V' with G. capricornis. 
- Gazella sp., represented by a single horn-core said to be very large, but whose measurements (c. $28 \times 25.4$ according to KÖHLER 1987, fig. 84) would also fit $G$. capricornis (see, e.g., Kostopoulos 2009b, fig.6).

- Palaeoreas cf. lindermayeri, represented by a single maxilla with P3-M2; such a piece cannot be identified, even at genus level.

- Oioceros wegneri, represented by the tip if a horn-core; members of the Oioceros group are characterized by their horn cores with homonymous torsion, but the tip of a horn-core cannot be sided, so the identification remains uncertain.

- Palaeoryx pallasi, represented by a mandible, a maxilla, and two horn-core fragments; measurements and figures of the specimens (KöHLER 1987, fig. 13 and 103) are satisfactory matches for the species, and this identification can be accepted.

\author{
Order Perissodactyla OwEN, 1848 \\ Family Rhinocerotidae GRAY, 1821 \\ Genus Ceratotherium GRAY, 1867 \\ Ceratotherium neumayri (OSBORN, 1900)
}

This species is represented by some postcranials and tooth-rows, and a cranium Ma2Gips 15, virtually complete and undistorted, which is, together with the specimen from Akkaşdağı (ANTOINE \& SARAÇ 2005) one of the best known specimens of this species, and the most valuable fossil of the SMNK collection from Mahmutgazi (Fig. 4A; comparative measurements: Table 5). The species is relatively well-known, and a detailed description of the cranium would be useless; I shall focus on the most significant points.

The cranium carried two horns, a large nasal ones, and a smaller, but distinct frontal one. Behind it, the dorsal profile is straight as far as the level of the middle of the temporal fossa, where it curves upwards towards the nuchal crest. Although well indicated, this concavity, in this undistorted skull, is much shallower than in the skull MTLA-5 from Samos (GIAOURTSAKIS 2009, pl.1, fig.1). This strongly suggests that distortion in this Samos skull was stronger than assumed by GIAOURTSAKIS (2009), as also indicated by the relatively short distance between the occipital condyles and M3, and the upward tilt of the zygomatic arch. In this relatively straight dorsal profile, Ma2-Gips 15 resembles modern C. simum, the African 'white' rhinoceros. The nuchal crest has a large flange-like caudal expansion, with a central notch; it largely overhangs the condyles, and is almost as broad as the ventral part of the occipital; the occipital surface is slightly inclined dorsocaudally, thus intermediate between the 
average conditions of $C$. simum and Diceros bicornis, the 'black' rhinoceros. The basioccipital and basisphenoid form a marked angle, a clear difference with $C$. simum, in which they are almost in line, in correlation with the much lengthened skull of the end members of the Ceratotherium lineage.

The rarely preserved premaxillae are complete; as usual in the Dicerotini, they bear no incisor, although small cavities may be the alveoli of vestigial ones. The bottom of the nasal notch is above the limit $\mathrm{P} 2 / \mathrm{P} 3$, the infra-orbital foramen is above $\mathrm{P} 4$, the front of the orbit above the middle of M2; these positions are similar to those observed in other $C$. neumayri (GERAADS 2005, fig.6). As in modern African rhinos, the lachrymal tubercle and supra-orbital process tend to fuse into an orbital rim, there is no post-orbital process, and the ventral orbital border is rounded.

The DP1 is shed, and the other cheek-teeth are well-worn. They are virtually identical with those of D. bicornis, a morphology that, in my opinion, confirms the hypothesis that $C$. neumayri is an acceptable ancestor for both $D$. bicornis and $C$. simum, although the latter has a much derived tooth morphology.

Ma2-Gips16 (Fig. 4C) is a maxilla with nasal notch and infra-orbital foramen slightly more posterior than in the skull, but again within the range of $C$. neumayri. The teeth are slightly less worn, but display the same characters, being very similar to those of D. bicornis. Their measurements are also similar to those of Ma2-Gips15 (occlusal length P2-P4 = 121; occlusal length M1-M3 = 145). There is no tooth anterior to P2, meaning that DP1 was shed, and not replaced; it seems that this is the rule in D. bicornis, although a true P1 may sometimes show up (MNHN-1961-195). The premolars have small cristae, as sometimes occurs in D. bicornis.

Ma3-Gips1 is a nice deciduous upper tooth-series, very similar to those figured by GERAADS $(1988,1994)$ and GiAOURTSAKIS (2009). Its size (L DP1-DP4 = $151 \mathrm{~mm}$ ) is within the range of Pikermi (GERAADS 1988), main Samos assemblage (GIAOURTSAKIS 2009), and slightly above that of the two specimens from Kemiklitepe A (GERAADS 1994). There are several lower deciduous series. They are comparable in size to those from MTLA (GIAOURTSAKIS 2009) but the talonid basin of dp2 is never fully closed, and the anterior lobe of $\mathrm{dp} 3$ is at most incipient; it may be that the intra-specific variability of these teeth is greater than assumed by GIAOURTSAKIS (2009).

It is more parsimonious to assume that post-cranials also belong to C. neumayri; indeed, they display some of the features regarded as characteristic of this taxon by GERAADS (1988) and GIAOURTSAKIS (2009). 
There are several sets of associated metacarpals (Fig. 4D). The McII has no palmar ridge and a long articular surface for the magnum, and the McIII has a deep lateral concavity to accommodate a strong tuberosity of the Mc IV (see also GIAOURTSAKIS 2009, pl. 5, figs.4-6). The three McIIIs are homogeneous in size (Table 6), and are slightly shorter than a specimen from Lubéron (MNHN), but slightly longer than a McIII from Garkın in München (1968-VI359), and than KTD-6 from the lower level of Kemiklitepe (GERAADS 1994). Although not too much weight should be placed upon these measurements, the metric evidence is consistent with a slight increase in metapodial length from KTD and Garkın to Mahmutgazi and to Lubéron. Ma2-Gips15 (Fig. 4B) is an astragalus showing the typical features of the species (GIAOURTSAKIS 2009): oval sustentacular facet separated from the distal calcanear facet, lateral fibular facet tapering proximally, not contacting the sustentacular facet. Ma2-Gips28 is an incomplete astragalus that differs in having a round sustentacular facet, and in being lower, but it may have suffered some distortion; I do not regard this single specimen as positive evidence of another species.

Thus, Ceratotherium neumayri is the only species definitely represented in the SMNK collection. HeISSIG (1975) mentioned Chilotherium schlosseri, but I have not seen a single specimen that could be assigned to Chilotherium.

\author{
Family Chalicotheriidae GILL, 1872 \\ Genus Ancylotherium GAUDRY, 1863 \\ Ancylotherium pentelicum (GAUDRY \& LARTET, 1856)
}

This strange and highly characteristic animal is represented by the poorly preserved proximal portions of left associated metacarpals, Ma2-Gips21 (Fig. 5H). Their length cannot be estimated, but what remains shows that they were stoutly built, and certainly shorter and less slender than those from Hadjidimovo (GERAADS et al. 2006b), more like those from Maragha (MECQUENEM 1924-25; Roussiakis \& THEODOROU 2001). The proximal epiphysis of the Mc III is broader than deep (in dorsopalmar direction), unlike all other specimens (Table 7), and the facet for the magnum is relatively broad. The meaning of this difference, and the post-cranial evolution of the species, which is present in the area since the Vallesian (KoufOS 2012), remain unknown. Ancylotherium was previously assumed to be a leaf browser, but both GERAADS et al. (2006b) and SCHULZ ET AL. (2007) came to the conclusion that it fed on bark or stems of large plants. This specialization may explain why it is always rare at any site, although present in many of them (map in GERAADS et al. 2006b). 
Family Equidae GRAY, 1821

I shall only briefly report on this group. STAESCHE \& SONDAAR (1979) mentioned that they included the Karlsruhe material in their study of the Turkish hipparions but, although they provide the measurements of a number of teeth, they do not mention postcranials from Mahmutgazi, and seemingly included all hipparions from this site in a single species, Hipparion matthewi.

The most significant fossils in the SMNK are eight metapodials and a number of upper and lower tooth-rows, but no remain includes the preorbital part of the skull, consistently used in hipparion systematics. The main measurements of six relatively complete metatarsals are plotted in Fig. 6; they clearly indicate the presence of two species, each with remarkably little intra-specific variation. The lengths of the bones of the two species are not very different, but the shorter ones are much more slender. The measurements of two metacarpals display the same pattern: one is shorter and much more slender than the other (I follow here the tradition in using Simpson diagrams, although in fact they show little more than gross differences in size; obviously, multivariate analyses would be better adapted but, beyond a brief attempt by KOUFOS \& VLACHOU [2005], they have been neglected).

Differences in tooth-row lengths (Table 8) are also quite clear, and the distribution of individual tooth lengths is clearly bimodal (STAESCHE \& SONDAAR 1979, fig. 26), confirming the existence of two species.

\section{Cremohipparion cf. matthewi (ABEL, 1926)}

There are two complete upper tooth-rows (Fig. 5D), one with P3-M3, probably also a mandible with the front teeth and the premolars, and some more or less lower complete toothrows (Fig. 5E-G). The length of the series P2-P4 ranges from 64 to $68 \mathrm{~mm}$, that of M1-M3 from 53 to $57 \mathrm{~mm}$. The protocone is large and rounded on the upper premolars, and tends to connect anteriorly to the protoloph; it is smaller and more transversally compressed on the molars. The pli caballin is small, and sometimes multiple on the premolars. On a mandible, the diastema is rather short and the third incisor looks unreduced, but the specimen is not fully adult.

The metapodials are shorter and more slender than all other Turkish specimens measured by STAESCHE \& SONDAAR (1979) from Kınık, Garkın, or Kayadibi, but are 
comparable with those of $C$. matthewi from Kemiklitepe A-B or Samos Q5 (Koufos \& VLACHOU 2005, figs.43-44).

Although no substantial part of the skull is preserved, the size of the tooth-rows, and those of the short, slender metapodials unambiguously indicate that this hipparion belongs to a group of small-size forms, of which Cremohipparion matthewi is the most common representative, and we tentatively assign the small hipparion from Mahmutgazi to this species.

Hipparionini gen. et sp. indet.

A larger form seems to be slightly more common but, except for its larger size and more robust metapodials, it does not display any significant difference, except that enamel plication is perhaps stronger (Fig. 5A-C). The premolars are relatively slightly shorter than in the $C$. $\mathrm{cf}$. matthewi. The size of the metapodials would fit several Late Miocene Aegean species, and I prefer not to suggest any identification.

Order Proboscidea ILLIGER, 1811

Genus Choerolophodon SCHLESINGER, 1917

Choerolophodon pentelici (GAUDRY \& LARTET, 1856)

The SMNK collection includes only a score of postcranials. Because late Miocene Proboscidean postcranials have been neglected, these bones neither confirm nor refute GAZIRY's (1976) identification of Choerolophodon pentelici, but since this identification was based upon a tooth fragment, it can be accepted.

\section{Biochronology}

Both the scarce field data and the study of the collection leave no doubt as to the contemporaneity of the faunas from Ma1 and Ma2, which can thus be regarded as a single one. The case of Ma3 is less clear, because the presence of Protictitherium crassum (see SCHMIDTKITTLER 1976) and of a Samotherium mandible of relatively small size might suggest an earlier age. However, as noted above, a photo preserved in the SMNK shows Ma3 almost exactly at the same stratigraphic level as Ma1 and Ma2, and two deciduous tooth-series of Ceratotherium neumayri (see above) fit within the range of typical Turolian forms. The issue cannot be definitely be settled but, on balance, Ma3 looks contemporaneous with the other spots, although it is safer to discuss it separately.

An updated faunal list based upon the present study but also taking into account previous identifications (SICKENBERG et al. 1975; GAZIRY 1976; SCHMIDT-KITTLER 1976; 
KÖHLER 1987; PICKFORD 1976) can now be provided (Table 9). I have not seen any material of Orycteropus, but the genus is so characteristic that the identification (BECKER-PLATEN et al. 1975) can be accepted. I list the carnivores as they were published, although the status of the primitive hyenids is unclear (WERDELIN \& SOLOUNIAS 1991), and the distinction between Machairodus aphanistus and later M. giganteus far from clear-cut.

This faunal list is rather short compared to many upper Miocene sites of the area, where Giraffidae and Rhinocerotidae are usually represented by more than one species. This is not merely due to the limited scale of the excavations because the Giraffidae and Rhinocerotidae, with about 80 and 40 specimens, respectively, make up a significant collection. It is likely that the accumulation process, whatever it was, very incompletely sampled the large mammal biocenosis; paleoecological inferences would not be strongly supported, but some biochronological comparisons with other Turkish sites can be proposed.

The Sinap Formation near Ankara includes some early Turolian faunas (in localities 26, 27, and 33 of Kavakdere) consisting mostly of fragmentary, hardly identifiable material. The large giraffid, however, is certainly distinct (GERAADS \& GÜLEÇ 2000), Prostrepsiceros zitteli is definitely present (GERAADS \& GÜLEÇ 1999), together with antelopes of the PachytragusProtoryx group (GENTRY 2003) and there are certainly at least two species of rhinos (ForTELIUS et al. 2003). The late Turolian locality of Çoban Pinar (Loc. 42) has the same antelopes of the Pachytragus-Protoryx group, plus Nisidorcas (GERAADS \& GÜLEÇ 1999), and a small suid (VAN DER MADE 2003).

Çorakyerler near Ankara (GERAADS 2013) much differs from Mahmutgazi, and is probably earlier. The dominant rhinoceros is a hornless form with large incisors, there is no form close to C. matthewi, no Samotherium, and the dominant bovids are spiral-horned forms; the only significant resemblance is the likely presence of 'Plesiaddax' inundatus.

Comparison with sites in Central and Western Turkey is more relevant. Unfortunately, the faunas from the other sites excavated under the leadership of O. SICKENBERG have also been very incompletely studied, so that the validity of the biochronology established by SICKENBERG et al. (1976) remains questionable. STAESCHE \& SONDAAR (1979) placed Mahmutgazi at the end of the Garkın faunal zone, or at the beginning of the Kınık one. It would thus be intermediate in age between Samos Q1/Q4 and Samos Q5, corresponding to what Koufos et al. (2009) called 'Dominant Mammal Assemblage' of Samos (DMAS).

Putting the various localities of Samos and Western Turkey in chronological order is difficult because, as shown by Table 9, most assemblages look like mere sub-samples of the DMAS, which is distinctly richer than the others. Inter-locality differences mostly concern taxa 
that are rare or hard to identify. Another problem is that the only fully studied group in all sites are the ruminants, which are poorly represented at Mahmutgazi.

Mahmutgazi is certainly younger that the lower part of the Samos sequence (PMAS), which has a distinctly more primitive species of Samotherium, but it can be observed that no other taxon of the PMAS confirms this early age. However, Protictitherium crassum, unknown afterwards, is a resemblance between both sites, if indeed Ma3 is contemporaneous with Ma1 and Ma2.

At Garkın, ERDBRINK (1978) defined 'Plesiaddax' inundatus that is probably also present at Mahmutgazi, but other listed taxa (BECKER-PLATEN et al. 1976) do not allow conclusions, although the site is traditionally regarded as transitional between zones MN 11 and 12 (meaning that these zones are not properly defined).

The lower level of Kemiklitepe (BONIS et al. 1994) is not very rich, but the metacarpals and astragali of Samotherium are smaller than those of Mahmutgazi, and there is an antelope that resembles Majoreas elegans from the Sinap, so that KTD can confidently be regarded as older than Mahmutgazi.

The upper levels of Kemiklitepe and the Intermediary Mammal Assemblage of Samos (IMAS) share a number of taxa with Mahmutgazi but none is very significant in terms of biochronology; the limb bones of Samotherium major are similar-sized, but a Chilotherium s.str. is present; I regard KTA-B and the IMAS as roughly contemporaneous with Mahmutgazi, or perhaps slightly younger.

The fauna from Şerefköy-2 has only been partly studied, but the Machairodus was listed as M. giganteus (KAYA et al. 2011), and some taxa also perhaps indicate a younger age (Parataxidea, Pliohyrax graecus, Urmiatherium rugosifrons); the only possible significant resemblance with Mahmutgazi is a very large bovid, assigned to Palaeoryx pallasi by KostOPOULOS \& KARAKÜTÜK (2015, fig. 4A-B), but reminiscent of the Mahmutgazi 'Plesiaddax', although its premolars are longer. I regard Mahmutgazi as older than Şerefköy-2, whose age was estimated at c. 6.8-7 Ma by KostOPOULOS \& KARAKÜTÜK (2015).

Akkaşdağ is a rich and fully studied locality in central Turkey (SEN 2005). Some of its taxa are unknown in Western Turkey, although paradoxically present in continental Europe (Tetralophodon, Chalicotheriinae, Thalassictis spelaea), but few are biochronologically significant; KOSTOPOULOS \& KARAKÜTÜK (2015) identified Skoufotragus schlosseri, a similarity with Şerefköy-2, and an age of c. 7.1 Ma has been proposed on the basis of radiometric dating (KARADENIZLI et al. 2005). The hyenid assemblage and the presence of Chilotherium suggest that Akkaşdağı is younger than Mahmutgazi but evidence is weak. 
Regarding previously published groups, the characters of the large carnivores studied by SCHMIDT-KiTTLER (1979), Machairodus and Adcrocuta, would fit any age in the Late Miocene, except perhaps its very beginning, but the large size of the Machairodus P3 is perhaps more indicative of a relatively ancient age. PICKFORD (2016) concluded that the size of the Mahmutgazi 'Hippopotamodon' plots in the lower half of the Pikermi and Samos ranges.

\section{Conclusions}

In summary, comparisons with other sites broadly agree with previous estimates made by HeISSIG (1975), BECKER-PlATEN (1975), or KÖHLER (1987), and I regard Mahmutgazi as earlier than Şerefköy-2, Akkaşdağı, or the DMAS, but younger than Kemiklitepe-D. I observe that assigning it to a 'MN zone' is not straightforward, thus demonstrating that these zones cannot be defined on the basis of large mammals in Turkey, and therefore have no meaning there. In fact, assignment of Aegean large mammal faunas to 'MN zones' usually rests upon the estimation of their age by comparison with other sites, or worse, with the help of some physical method. Because their existence is not implied by the facts (e.g., at Samos, most of the faunal changes occur within 'MN 12' [KoufOS et al. 2009, fig. 2]), and because they have no practical use there, dropping these 'zones' from use would not hinder progress in Aegean Miocene biochronology.

\section{Acknowledgments}

I am grateful to Wolfgang MUNK for welcoming me at the SMNK and for much help there, to Martin PICKFORD for calling my attention to the Mahmutgazi collection, and to the reviewer, Dimitris S. Kostopoulos, for his enlightened comments.

\section{References}

AnTOINE, P.-O. \& SARAÇ, G. (2005): Rhinocerotidae (Mammalia, Perissodactyla) from the late Miocene of Akkaşdağ1, Turkey. Geodiversitas, 27: 601-632.

BeCKer-Platen, J.D., SicKenBERG, O. \& ToBien, H. (1975): Vertebraten-Lokalfaunen der Türkei und ihre Alterstellung. Geologisches Jahrbuch B, 15: 47-100.

Bohlin, B. (1926): Die Familie Giraffidae. Paleeontologia Sinica C, 4(1): 1-178.

Bonis L. DE (2005): Carnivora from the late Miocene of Akkaşdağı, Turkey. Geodiversitas, 27: 567-589.

Bonis L. DE, Bouvrain G., GeraAds D. \& SEN S. (1994): Les gisements de Mammifères du Miocène supérieur de Kemiklitepe, Turquie: 11. Biochronologie, paléoécologie, et 
relations biogéographiques. Bulletin du Muséum national d'Histoire naturelle, $4^{\text {ème }}$ sér., C, 16: 225-240.

ERDBRINK, D.P.B. (1978). Fossil ovibovines from Garkın near Afyon, Turkey. Proceedings of the Koninklijke Akademie van Wetenschappen B, 81: 145-185.

Fortelius, M., Heissig, K., SARAÇ, G. \& SEN, S. (2003): Rhinocerotidae (Perissodactyla). In: Fortelius, E., Kappelmann, J., Sen, S. \& Bernor, R. (Eds): Geology and Paleontology of the Miocene Sinap Formation, Turkey, 282-307, New York (Columbia University Press).

GAZIRY, A.W. (1976): Jungtertiäre Mastodonten aus Anatolien (Türkei). Geologisches Jahrbuch, 22: 3-143.

GENTRY, A.W. (2003): Ruminantia (Artiodactyla) - In: Fortelius, E., KAPPELMANn, J., SEN, S. \& BERNOR, R. (Eds): Geology and Paleontology of the Miocene Sinap Formation, Turkey, 332-379, New York (Columbia University Press).

GERAADS, D. (1974): Les Giraffidés du Miocène supérieur de la région de Thessalonique (Grèce). Thesis, University Paris VI.

GERAADS, D. (1988): Révision des Rhinocerotidae (Mammalia) du Turolien de Pikermi. Comparaison avec les formes voisines. Annales de Paléontologie, 74: 13-41.

GERAADS, D. (1994): Les gisements de Mammifères du Miocène supérieur de Kemiklitepe, Turquie: 4: Rhinocerotidae. Bulletin du Muséum National d'Histoire Naturelle, $4{ }^{\text {ème }}$ sér., C, 16: 81-95.

GERAADS, D. (2005): Pliocene Rhinocerotidae (Mammalia) from Hadar and Dikika (Lower Awash, Ethiopia), and a revision of the origin of modern African rhinos. Journal of Vertebrate Paleontology, 25: 451-461.

GERAADS, D. (2013): Large Mammals from the late Miocene of Çorakyerler, Çankırı, Turkey. Acta zoologica Bulgarica. 65: 381-390.

GERAADS, D. \& GÜLEÇ, E. (1999): On some spiral-horned antelopes from the upper Miocene of Turkey, with remarks on their distribution. Paläontologische Zeitschrift, 73: 403409.

GERAADS, D. \& GÜLEÇ, E. (2000): A Bramatherium skull (Giraffidae, Mammalia) from the upper Miocene of Kavakdere (Central Turkey). Biogeographic and phylogenetic implications. Mineral Resources and Exploration Bulletin, 121: 51-56.

GeraAdS, D. \& Koufos, G. (1990): Upper Miocene Rhinocerotidae (Mammalia) from Pentalophos-1, Macedonia, Greece. Palaeontographica A, 210: 151-168. 
GERAADS, D. \& SpASSOv, N. (2009): Rhinocerotidae from the late Miocene of Bulgaria. Palaeontographica A, 287: 99-122.

GERAADS, D., KAYA T. \& TUNA V. (2004): A skull of Machairodus giganteus (Felidae, Mammalia) from the Late Miocene of Turkey. Neues Jahrbuch für Geologie und Paläontologie Monatshefte, 2004: 95-110.

GeraAds, D., Spassov, N. \& Kovachev D. (2005): Giraffidae (Artiodactyla, Mammalia) from the late Miocene of Kalimantsi and Hadjidimovo, South-Western Bulgaria. Geologica Balcanica, 35: 11-18.

GeraAds, D., Spassov, N. \& Kovachev, D. (2006a): A new Sporadotragus (Bovidae, Mammalia) from the late Miocene of Bulgaria. Rivista Italiana di Paleontologia e Stratigrafia, 112: 473-479.

GeraAds, D., Spassov, N. \& Kovachev, D. (2006b): The Bulgarian Chalicotheriidae (Mammalia): an update. Revue de Paléobiologie, 25: 429-436.

GiaOURTSAKIS, I.X. (2009): The late Miocene Mammal faunas of the Mytilinii Basin, Samos Island, Greece: new collection. 9. Rhinocerotidae. Beiträge zur Paläontologie, 31: 157187.

GUERIN, C. (1980): Les Rhinocéros (Mammalia, Perissodactyla) du Miocène terminal au Pléistocène supérieur en Europe occidentale. Comparaison avec les espèces actuelles. Documents des Laboratoires de Géologie de la Faculté des Sciences de Lyon, 79: 11185 .

HEISSIG, K. (1975): Rhinocerotidae aus dem Jungtertiärs Anatoliens. Geologisches Jahrbuch B, 15: 145-151.

Karadenizli, L., SeyitoĞlu, G., Sen, S., Arnaud, N., KaZanci, N., Saraç, G., AlçiçeK, C. (2005): Mammal bearing late Miocene tuffs of the Akkaşdağı region: distribution, age, petrographical and geochemical characteristics. Geodiversitas, 27: 553-566.

Kaya, T.S., Mayda, S., Kostopoulos, D.S., AlçiçeK, M.C., Merceron, G., Tan, A., KARAKÜTÜK, S., GIESLER, A.K. \& SCOTT, R.S. (2011): Şerefköy-2, a new Late Miocene mammal locality from the Yatağan Formation, Muğla, SW Turkey. Comptesrendus Palevol, 11: 5-12.

KÖHLER, M. (1987): Boviden der türkischen Miozäns. Paleontología i Evolució, 21: 133-246. Kostopoulos, D.S. (2005): The Bovidae (Mammalia, Artiodactyla) from the late Miocene of Akkaşdağı, Turkey. Geodiversitas, 27: 747-791.

Kostopoulos, D.S. (2009a): The late Miocene Mammal faunas of the Mytilinii Basin, Samos Island, Greece: new collection. 13. Giraffidae. Beiträge zur Paläontologie, 31: 299-343. 
Kostopoulos, D.S. (2009b): The late Miocene Mammal faunas of the Mytilinii Basin, Samos Island, Greece: new collection. 14. Bovidae. Beiträge zur Paläontologie, 31: 345-389. Kostopoulos, D.S. \& KARAKÜTÜK, S. (2015): Late Miocene bovids from Şerefköy-2 (SW Turkey) and their position within the sub-Paratethyan biogeographic province. Acta Palaeontologica Polonica, 60: 49-66.

Kostopoulos, D.S. \& SARAÇ, G. (2005): Giraffidae (Mammalia, Artiodactyla) from the late Miocene of Akkaşdağ1, Turkey. Geodiversitas, 27: 735-745.

Koufos, G.D. (1987): Study of the Pikermi hipparions. Part I: generalities and taxonomy. Bulletin du Muséum national d'Histoire naturelle, Paris, 4ème série, C, 9: 197-252. Koufos, G.D. (2012): New material of Chalicotheriidae (Perissodactyla, Mammalia) from the Late Miocene of Axios Valley, Macedonia (Greece) with the description of a new species. Annales de Paléontologie, 98: 203-224.

Koufos, G.D. \& Vlachou, T.D. (2005): Equidae (Mammalia, Perissodactyla) from the late Miocene of Akkaşdağı, Turkey. Geodiversitas, 27: 633-705.

Koufos, G.D., Kostopoulos, D.S. \& Vlachou, T.D. (2009): The late Miocene Mammal faunas of the Mytilinii Basin, Samos Island, Greece: new collection. 16.

Biochronology. Beiträge zur Paläontologie, 31: 397-408.

MECQUENEM, R. DE (1924-1925): Contribution à l'étude des fossiles de Maragha. Annales de Paléontologie, 13: 135-160; 14: 1-36.

PICKFORD, M. (2016): Hippopotamodon erymanthius (Suidae, Mammalia) from Mahmutgazi, Denizli-Çal basin, Turkey. Fossil Imprint, 72: 183-201.

Rodler, A. \& Weithofer, K.A. (1890): Die Wiederkäuer der Fauna von Maragha.

Denkschriften der kaiserlichen Akademie der Wissenschaften, Math.Naturw. Kl., 57: 753-771.

Roussiakis, S.J. \& THEODOROU, G.E. (2001): Ancylotherium pentelicum (Gaudry \& Lartet, 1856) (Perissodactyla, Mammalia) from the classic locality of Pikermi (Attica, Grece), stored in the palaeontological and geological museum of Athens. Geobios, 34: 563584.

SARAÇ, G., KAYA, T. \& GERAADS, D. (2002): Ancylotherium (Ancylotherium) pentelicum (Perissodactyla, Mammalia) from the Upper Miocene of central and western Turkey. Geobios, 35: 241-251.

SCHMIDT-KitTLER, N. (1976): Carnivores from the Neogene of Asia Minor. Palaeontographica A, 155: 1-131. 
Schulz, E., FAhlKe, J.M., Merceron, G. \& Kaiser, T.M. (2007): Feeding ecology of the Chalicotheriidae (Mammalia, Perissodactyla, Ancylopoda). Results from dental microand mesowear analyses. Verhandlungen des Naturwissenschaftlichen Vereins in Hamburg, 43: 5-31.

SEN, S. (2005): Geology, mammals and environments at Akkaşdağı, late Miocene of central Anatolia. Geodiversitas, 27: 513-830.

SICKENBERG, O. et al (1975): Die Gliederung des höheren Jungtertiärs und Altquartärs in der Türkei nach Vertebraten und ihre Bedeutung für die internationale NeogenStatigraphie. Geologisches Jahrbuch B, 15: 1-167.

Spassov, N. \& GERAADS, D. (2004): Tragoportax Pilgrim and Miotragocerus Stromer (Mammalia, Bovidae) from the Turolian of Hadjidimovo, Bulgaria, and a revision of the Late Miocene Mediterranean Boselaphini. Geodiversitas, 26: 339-370.

StAesche, U. \& SondAAR, P.Y. (1979): Hipparion aus dem Vallesium und Turolium (Jungtertiär) der Türkei. Geologisches Jahrbuch B, 33: 35-79.

TASSY, P. (2005): Proboscideans (Mammalia) from the late Miocene of Akkaşdağı, Turkey. Geodiversitas, 27: 707-714.

VALLI, A.M.F. (2005): Taphonomy of the late Miocene mammal locality of Akkaşdağı, Turkey. Geodiversitas, 27: 793-808.

VAn Der MAdE, J. (2003): Suoidea (Artiodactyla) - In: Fortelius, E., KAPPELMAnN, J., SEn, S. \& BERnOR, R. (Eds): Geology and Paleontology of the Miocene Sinap Formation, Turkey, 308-327, New York (Columbia University Press).

WeRdELIN, L. \& Solounias, N. (1991): The Hyaenidae: taxonomy, systematics and evolution. Fossils and Strata, 30: 1-104. 
Captions to figures

Fig. 1. Artiodactyla from Mahmutgazi. A-L, Samotherium major. A: left mandible Ma3 (A1: occlusal view; A2: lateral view of the rostral part). B, maxilla with P3-M2 Ma2-Gips29. C-D: tibiae in anterior view (C: MA2-Gips16; D: Ma2-Gips11). E: distal humerus n54, anterior view. F-H: metacarpals in anterior view (F: Ma2-Gips17; G and H: Ma2-Gips20). I: cubonavicular Ma1-Gips10, distal view, to show the absence of plantar metatarsal facet. J: astragalus Ma1-Gips10, anterior view. K: upper deciduous tooth-row Ma1-Gips3. L: lower dp3-dp4 Ma1-Gips11. M: Tragoportax sp., right upper tooth row. N: Miotragocerus (Pikermicerus) gaudryi, left lower tooth-row. Scale bar $=5 \mathrm{~cm}$ for Figs. M-N, $10 \mathrm{~cm}$ for Figs. A, B, and I-L, $25 \mathrm{~cm}$ for Figs C-H.

Fig. 2. Plot of length vs. distal width of late Miocene giraffid metacarpals (KTA = Kemiklitepe, upper level; Slq = lower Axios valley, ARAMBOURG'S collection). Data from KosTOPOULOS (2009a), and original measurements.

Fig. 3. Plot of medial length vs. distal width of late Miocene giraffid astragali. Note that 'Maragha' includes both S. neumayri and Palaeotragus coelophrys. Data from KosTOPOULos (2009a), and original measurements.

Fig. 4. Ceratotherium neumayri from Mahmutgazi. A: skull Ma2-Gips15 (A1: lateral view; A2: ventral view; A3: occipital view). B: astragalus Ma2-Gips15 (B1: plantar view; B2: lateral view; B3: anterior view). C: upper tooth row Ma2-Gips16, occlusal view. D: set of left metacarpals Ma1-94. Scale bar $=20 \mathrm{~cm}$ for Figs. A and D, $10 \mathrm{~cm}$ for Fig. B and C.

Fig. 5. Perissodactyla from Mahmutgazi. A-C: Hipparionini gen. et sp. indet. (A: upper P2-M3 Ma2-Gips24; B: upper P2-M3 Ma2-Gips3; C: lower p2-m3 'M' [reversed from the right side]). D-G: Cremohipparion cf. matthewi (D: upper P2-M3 Ma1-Gips 17 [reversed from the left side]; E: lower p3-m3 'K'; F: lower p2-m2 'H'; G: lower p3-m3 'J' [reversed from the right side]). H: Ancylotherium pentelicum, front view of proximal metacarpals Ma2-Gips21. Scale bar $=5 \mathrm{~cm}$ for Figs. A-G, $10 \mathrm{~cm}$ for Fig. $\mathrm{H}$.

Fig. 6. Simpson graphs of hipparionine metapodials. I chose to use Cremohipparion mediterraneum from Pikermi (KoUfOS 1987) as a standard, because this species is more relevant than the central European Höwenegg form. 1 = maximum length; 3 = width of shaft; 5 
$=$ proximal breadth $; 10=$ distal supra-articular width; $11=$ distal articular width; $12=$ maximum distal antero-posterior diameter. 